Accepted for publication in the Journal of Business \& Industrial Marketing

28 April 2020

Market shaping dynamics: Interplay of actor engagement and institutional work

Julia A. Fehrer

The University of Auckland Business School, Auckland, New Zealand University of Bayreuth, Bayreuth, Germany

Jodie Conduit

University of Adelaide Business School, Adelaide, Australia

Carolin Plewa

University of Adelaide Business School, Adelaide, Australia

Loic Pengtao Li

The University of Auckland Business School, Auckland, New Zealand

Elina Jaakkola

University of Turku School of Economics, Turku, Finland

Matthew Alexander

University of Strathclyde Business School, Glasgow, UK

Please do not distribute or cite this manuscript without the authors' permission. 


\title{
Market shaping dynamics: Interplay of actor engagement and institutional work
}

\begin{abstract}
Purpose: Combining institutional work and actor engagement (AE) literature, this paper aims to elucidate how the collective action of market shaping occurs through the interplay between market shapers' institutional work and engagement of other market actors. While markets are shaped by actors' purposive actions, and recent literature notes the need to also mobilize AE, the underlying process remains nebulous.

Design/methodology/approach: This paper is conceptual but supported by an illustrative case study: Winding Tree. This blockchain-based, decentralized travel marketplace shapes a market by decoupling existing resource linkages, creating new ones, and stabilizing others through a dynamic, iterative process between the market shaper's institutional work and others' AE.

Findings: The paper develops a dynamic, iterative framework of market shaping through increased resource density, revealing the interplay between seven types of market shapers' institutional work distilled from the literature and changes in other market actors' engagement dispositions, behaviors and the diffusion of $\mathrm{AE}$ through the market.

Originality/value: This research contributes to the emergent market shaping and market innovation literature by illustrating how the engagement of market actors is a fundamental means of market shaping. Specifically, it advances understanding of how market shapers' institutional work leads to new resource linkages and higher resource density in emergent market systems through AE. The resultant framework offers an original, critical foundation for future market shaping research.
\end{abstract}

Keywords: Market shaping, actor engagement, institutional work, complex market systems, resource density, blockchain marketplace

Paper type: Conceptual paper 


\section{Introduction}

As firms face increasingly fundamental shifts in their environment, many are proactively shaping markets in practice to fashion contexts where they can flourish. Meanwhile, based on the foundation of performativity theories in the economics and sociology literatures (Aspers, 2007), the marketing academy recognizes that markets are malleable, emergent and dynamic systems, thus supplying theory on how firms can initiate changes to shape markets and create value in their favor (Nenonen et al., 2014). This understanding of markets as systems that can be formed and re-formed underpins the growing body of research on market shaping, considered as focal actors' purposive actions to facilitate the "emergence and institutionalization of resource linkages that improve resource density and, hence, value creation in a market" (Storbacka, 2019, p. 8).

Recent research elucidates the relevance of institutions for market shaping, as these provide the "rules of the game" for markets and hence guide interactions between market actors (Baker et al., 2018). Indeed, institutions are the foundation for resource integration and value creation (Vargo and Lusch, 2016; Wieland et al., 2016). Institutions can be changed (Battilana and D'Aunno, 2009) by deliberate actions, as framed in the literature on institutional work (Lawrence and Suddaby, 2006). But market shapers cannot change the market or its rules unaided; they must engage other market actors to join them in aligning behaviors according to the envisaged new rules of the game, thus effectively helping realize those rules. Take Airbnb. This giant of the sharing economy could not have shaped the hotel industry without engaged private hosts who rented out their homes. Nor could Shopify have shaped a growing ecommerce marketplace - with more than a million merchants and counting - without the engagement of thousands of freelancers, digital marketing agencies and other trusted experts forming and developing this marketplace. 
This paper follows a call by Storbacka (2019) and argues that for market shaping to develop requires understanding the important role of actor engagement (AE) in reinforcing and driving institutional change, fueled by purposive actions of the market shaper. As that article states, market systems, being complex, neither obey linear cause-effect relationships, nor revolve around one center of control. Instead, they follow a combinatorial logic of shaping and forming through the market shapers' deliberate actions paired with the engagement of other market actors who align with and build on these actions. Yet this dynamic interplay between market shapers' institutional work and the engagement of other market actors has received little attention in the institutional work and market shaping literature. Most institutional work studies have focused on changes at an organizational micro-level (Baker et al., 2018). Only very recently have Baker and Nenonen (2020) broadened the understanding of institutional work, which typically still considers the actions of one focal actor, to what they call "market work" undertaken by collective actors. Complementing this insight, the purpose of this paper is to elucidate how such collective action of market shaping occurs through the interplay between the market shaper's institutional work and the engagement of other market actors. This is a conceptual paper. It contributes to the emergent market shaping and market innovation literature by developing a dynamic framework for market shaping, which accounts for the complexity of market systems. It sheds light on the dynamic, iterative process of market shapers' deliberate efforts to influence institutional change and the engagement of other market actors, as the interplay between the two crucially intensifies resource density in the market system. A case study illustrates the paper's conceptual development: the new blockchain-based, decentralized travel marketplace, Winding Tree.

The article first discusses the complexity of market systems and the role of actors, institutions and resource linkages in such complex systems. Secondly, it reviews the developments in the institutional work literature and distills seven types of institutional work 
of special relevance to a broader system-level conception. In the third of the sections below, the $\mathrm{AE}$ literature is reviewed, highlighting the convergence of $\mathrm{AE}$ toward a more processoriented and systemic understanding. To build the dynamic framework, the fourth section borrows from these reviews and systematically combines market shapers' institutional work with the process of engaging other market actors, illustrated by examples from the Winding Tree case. The paper culminates in a discussion of implications, both a research agenda and implications for managers, entrepreneurs and public policy makers followed by a brief conclusion.

\section{Market shaping: Conceptualizing actors, institutions and resource linkages}

Markets are viewed in this paper as socially-constructed phenomena consisting of actors and institutions (Araujo, 2007; Gosling et al., 2017; Mele et al., 2014; Storbacka and Nenonen, 2011). More specifically, institutions guide how resources are integrated, how value creation is perceived and how representational views on markets are formed (Edvardsson et al., 2011; Vargo, et al., 2015; Vargo and Lusch, 2016; Wieland et al., 2016). Aligning with Wieland et al. (2016), this paper regards institutions as humanly devised meanings, norms, and rules that both enable and constrain the behavior of social and market actors and make social life and economic action predictable and meaningful (North, 1990; Scott, 2014).

Baker et al. (2018) show that marketing scholars have only latterly addressed links between markets and institutional arrangements (i.e. multiple, interrelated institutions, which interact and overlap, Vargo and Lusch, 2016). They point to a recent but growing stream of

marketing research using neo-institutional theory to explore market change and market innovation based on institutional change (e.g. Mele et al., 2014; Storbacka and Nenonen, 2015). This research stream provides a grasp of markets as systems, where various actors, not only producers and users, drive market innovation (Möller and Rajala, 2007). Indeed, market 
systems do not obey linear cause-effect relationships, nor do they have one center of control (Storbacka, 2019). Instead, they follow a combinatorial logic of shaping and forming through market shapers' deliberate actions on the one hand, paired on the other with engagement of other market actors who align with and build on these actions. For example, in cryptocurrency markets such as Bitcoin or Ethereum an initial team of developers constituting the market shapers create the blockchain, with thousands of developers going on to use the code by aligning their engagement to further shape the market.

Truly comprehending these market system complexities requires understanding them at different levels, while acknowledging these levels are arbitrary and relative to a market actor's viewpoint: (see Vargo and Lusch, 2016). All levels - micro (i.e. individual actors such as customers and suppliers), meso (e.g. legislators, industries) and macro (e.g. society) - of market systems (Battilana and D'Aunno, 2009) comprise institutional arrangements. These overlapping and potentially competing arrangements supply the structures for reconfiguring resource linkages (i.e. decoupling, creation and stabilizing), and thus for heightening resource densities (Storbacka, 2019; Vargo et al., 2015).

Heightened resource density is critical to effective market shaping (Storbacka, 2019). Resource density depends on the "availability and combination of resources that can be integrated in a particular context by the market actors" (Normann, 2001, p. 27) and thus how far an actor can access or mobilize resources at a particular time and in a particular space (Storbacka and Nenonen, 2011). Increasing resource density is an important driver for value creation in market systems, since market actors can draw from and mobilize a broader variety of accessible resources and integrate these resources with their own. The sharing economy, for example, one of the most significant market innovations of the last decade, adheres closely to the idea of increasing resource densities between two or more sides of the market, thereby creating value for all actors in the market system. 
Storbacka (2019) argues that undertaking purposive efforts to increase resource density, in other words market shaping, requires grasping the dynamic interplay of the market shaper's deliberate effort (referred to in the institutional literature as institutional work; Lawrence et al., 2009) and the engagement of other market actors. The remainder of this paper will discuss theoretically the dynamics of AE and institutional work for market shaping, beginning with the latter, and illustrate where appropriate with the case of Winding Tree.

\section{Market shapers' institutional work}

Institutional work draws on various streams of sociology and institutional theory, including social practice theory (Bourdieu, 1990; Schatzki et al., 2001) and structuration theory (Giddens, 1984). Defined as "the purposive actions of individuals and organizations aimed at creating, maintaining and disrupting institutions" (Lawrence and Suddaby, 2006, p.215), institutional work recognizes the agency of focal actors to affect change in markets intentionally, strategically and creatively (Raviola and Norbäck, 2013). Like the best-laid plans of mice and men though actors' creative and knowledgeable work, can go awry: in this case it may interact with existing social and technological structures in unintended and unexpected ways, so may or may not achieve its desired ends (Lawrence and Suddaby, 2006). However, intentionality goes to the heart of institutional work (Raviola and Norbäck, 2013) - for, true to the word "work", institutional work inherently involves "actors engaged in a purposeful effort to manipulate the institutional context they operate in" (Phillips and Lawrence, 2012, p. 224).

While most institutional work studies have focused on changes that occur at the organizational micro-level, changes can occur at any institutional level, including the market itself (Baker et al., 2018). Institutional work provides a conceptualization for both institutional change and institutional maintenance (Baker et al., 2020). Inspired by institutional work, Baker and Nenonen (2020) recently coined the concept of market work - the purposeful effort by 
market shapers to perform and transform markets. Those authors broaden the understanding of institutional work studies, which typically consider the actions of one focal actor, to this newly defined market work undertaken by collective actors. They thereby contribute to understanding how complex market systems are shaped.

The present paper's review of the institutional work literature uncovered seven types of institutional work with relevance for changing institutional arrangements on a market level: (1) undermining the current market leader; (2) framing (new) meaning by developing a new ideology and values; (3) governing and guiding activities through the creation of new rules and structures; (4) creating and diffusing knowledge within the market system; (5) building legitimacy to win the support of market actors; (6) empowering and negotiating with the network; and (7) reinforcing the network to maintain and grow the new market system. A synthesis of the literature can be found in Table 1, building on Baker et al. (2020). Now, current literature concurs that institutional work variously concerns the categories of creation, change/disruption and maintenance of institutions and institutional arrangements on various system levels (Baker et al., 2020). However, there is no one definitive list of generic institutional work types (Nenonen et al., 2018) - types of institutional work vary depending on the context and level of analysis. Nor does this catalogue of seven types claim to be definitive. However, the seven can nevertheless usefully be delineated and then grouped under those three broad categories. 
Table 1. Institutional work relevant for market shaping

\begin{tabular}{|c|c|c|}
\hline $\begin{array}{l}\text { Institutional outcomes on } \\
\text { market level }\end{array}$ & Market shapers' institutional work & References \\
\hline \multirow{4}{*}{ Change/disruption } & Undermining & e.g. Lawrence and Suddaby (2006), \\
\hline & Questioning current market leaders & $\begin{array}{l}\text { Micelotta and Washington (2013); } \\
\text { similarly, Baker and Nenonen (2020) }\end{array}$ \\
\hline & Framing meaning & $\begin{array}{l}\text { refer to demonizing } \\
\text { e.g. Helfen and Sydow (2013). Jones and }\end{array}$ \\
\hline & Developing a new ideology and values & Massa (2013) \\
\hline \multirow{3}{*}{ Creation } & $\begin{array}{l}\text { Governing and guiding } \\
\text { Creating new rules and systems for } \\
\text { doing things }\end{array}$ & $\begin{array}{l}\text { e.g. Lawrence and Suddaby (2006); } \\
\text { Lawrence et al. (2013) }\end{array}$ \\
\hline & $\begin{array}{l}\text { Creating and diffusing knowledge } \\
\text { Piloting and experimenting within the } \\
\text { market system }\end{array}$ & $\begin{array}{l}\text { e.g. Laukkanen and Patala (2014); } \\
\text { similarly, Lawrence and Suddaby (2006) } \\
\text { refer to educating }\end{array}$ \\
\hline & $\begin{array}{l}\text { Building legitimacy } \\
\text { Ongoing effort to win the support of } \\
\text { diverse network partners }\end{array}$ & $\begin{array}{l}\text { e.g. Baker and Nenonen (2020), Zietsma } \\
\text { and Lawrence (2010) }\end{array}$ \\
\hline \multirow{2}{*}{ Maintenance } & $\begin{array}{l}\text { Empowering and negotiating } \\
\text { Balancing the complex interplay of } \\
\text { negotiating with and empowering } \\
\text { market actors to overcome institutional } \\
\text { resistance }\end{array}$ & $\begin{array}{l}\text { e.g. Helfen and Sydow (2013); similarly } \\
\text { Baker and Nenonen (2020); similarly } \\
\text { too, Lawrence and Suddaby (2006) refer } \\
\text { to ensuring adherence in this context }\end{array}$ \\
\hline & $\begin{array}{l}\text { Reinforcing the network } \\
\text { Ongoing efforts to maintain and grow } \\
\text { the new market system }\end{array}$ & $\begin{array}{l}\text { e.g. Micelotta and Washington (2013); } \\
\text { similarly, Lawrence and Suddaby (2006) } \\
\text { refer to reproducing existing norms and } \\
\text { belief systems }\end{array}$ \\
\hline
\end{tabular}

\section{Market actors' engagement}

The concept of engagement captures today's ever-more collaborative and interactive marketplaces, where boundaries between individual customers and organizations blur. Initial conceptualizations of customer engagement considered the dyadic interaction between customers and the firm and they defined engagement as the activities customers undertake beyond their traditional roles as buyers and users of market offerings (Jaakkola and Alexander, 2014; van Doorn et al., 2010). While some conceptual approaches concentrated specifically on engagement behaviors, such as customer referrals (e.g. van Doorn et al, 2010), a common 
standard emerged recognizing customer engagement as a multidimensional construct with cognitive, affective and behavioral facets (Brodie et al., 2011).

In recent years, the conceptual domain of engagement research has widened by considering roles that more diverse sets of actors such as employees, citizens, and organizations play in engaging within their networks (Alexander et al., 2018; Jaakkola et al., 2019; Storbacka et al., 2016). This "actor-to-actor" perspective on engagement not only acknowledges interactions among multiple actors beyond the dyad, but also reflects the reciprocal, social, and collective nature of engagement (Alexander et al., 2018; Brodie et al., 2019; Kleinaltenkamp et al., 2019). In line with this work, $\mathrm{AE}$ is well defined as "a dynamic and iterative process that reflects actors' dispositions to invest resources in their interactions with other connected actors in a service system" (Brodie et al., 2019, p. 2). Adopting and applying this definition, the present authors agree that AE develops within broader institutional structures and note the interplay between the micro, meso, and macro system levels identified in earlier research (Alexander et al., 2018).

It is the interconnected nature of engagement that is of interest when thinking about the role of $\mathrm{AE}$ in market shaping. Engagement manifests through AE behaviors, whereby market actors influence each other's dispositions and behaviors (Alexander et al., 2018). Engagement behaviors hence systematically contribute to the creation, decoupling and stabilizing of resource linkages and thereby increase resource density and value creation in the market (Jaakkola and Alexander, 2014). For example, when Airbnb guests write reviews of a certain host, in a display of engagement behavior, they integrate their knowledge and experience and other resources and create new resource linkages for the host's next would-be guests. By engaging in this process, existing guests intensify resource density both on the travel platform and in the market system. 
Researchers also note ways engagement is related to institutional arrangements and observe that institutional arrangements both affect, and are affected by, actors' engagement behaviors (Verleye et al., 2014). This means that engagement dispositions are at once shaped by the behaviors of various other actors and shape institutional arrangements (Brodie et al., 2019). For example, in an organizational context (Sharma and Conduit, 2016), clients are invited to participate in strategic design workshops and hence demonstrate co-development engagement behavior (Jaakkola and Alexander, 2014). This behavior shapes institutional arrangements in the form of the organization's strategy and culture, fostering further engagement behavior.

"Zooming out" beyond a micro-level reveals the broader institutional structures that govern engagement (Alexander et al., 2018; Brodie et al., 2019; Kleinaltenkamp et al., 2019). As all actors - customers, customer communities, partners, suppliers, policymakers, and so forth - are embedded in institutional arrangements, all actions by any market actor take place within a larger socio-cultural frame (Baker et al., 2020; Edvardsson et al., 2014). For example, extant engagement research reveals how engagement in online brand communities affects the valence of customer interactions with a brand, besides stimulating community development among customers (Bowden et al., 2017). When an actor engages with a brand community, their disposition regarding what is acceptable and "good" recalibrates to the beliefs and values shared in the community; but, at the same time, that actor also both reinforces and changes such community norms through engagement behaviors (Alexander et al., 2018).

As engagement behaviors (such as augmenting and co-developing offerings or mobilizing and influencing other actors: Jaakkola and Alexander, 2014) facilitate contagion among actors in market systems, new shared sets of rules, knowledge about how to behave, and sets of norms (i.e. new institutional arrangements) form and stabilize (Alexander et al., 2018). The impact of these new institutional arrangements grows with how connected each 
actor is to a specific reference group (Brodie et al., 2019; Kleinaltenkamp et al., 2019). Thus, while institutional work initiates the creation, changing or maintenance of institutional arrangements, $\mathrm{AE}$ can be viewed as the process that reinforces, diffuses or potentially challenges the institutional work of the market shaper. Consequently, the interplay between the market shaper's institutional work and the AE of other market actors leads to the decoupling, creation and stabilizing of resource linkages in market systems.

While there is evidence of firms purposely, and strategically, initiating and influencing engagement either through engagement marketing (Harmeling et al., 2017), engagement platforms (Breidbach and Brodie, 2017) or through firm-initiated brand community engagement (Brodie et al., 2013), little is known about how engagement can be stimulated, and subsequently unfolds, on a broader market level. Hence, the remainder of this paper makes a first attempt to fuse the process of AE with the market shapers' institutional work and show in a dynamic framework how this combination can lead to the increase in resource density and consequently, market shaping. The case of a blockchain-based, decentralized travel marketplace -Winding Tree - serves to exemplify the paper's conceptual development.

\section{Interplay of market shapers' institutional work and market actors' engagement}

The above sections establish that changes in resource configurations leading to increasing resource densities create value in, and shape, market systems. Thus, arguably, the decoupling, creation and stabilizing of resource linkages fundamentally constitute market shaping. Figure 1 illustrates the iterative and dynamic interplay between market shapers' institutional work and the engagement of market actors; an interplay that leads to reconfiguring resource linkages and so to heightened resource density. Identified here, for illustrative purposes, are discrete connections between dimensions of institutional work, AE and increasing resource density in the market. However, it is important to reiterate, that this dynamic interplay may unfold in 
multiple ways through multiple feedback loops between market shapers and other engaged market actors, and that during the engagement process those engaged actors may themselves at some point become market shapers.

To unpack this complex dynamic framework, the next three sections respectively detail how decoupling existing resource linkages, creating new ones and stabilizing others can shape market systems based on the interplay of the market shaper's institutional work paired with other market actors' engagement. Tables 2, 3 and 4 accompanying these sections respectively compile key illustrative quotes from the Winding Tree website and other publicly available information support the theoretical argument. 
Figure 1. Dynamic framework for market shaping: Interplay of market shapers’ institutional work and market actors' engagement

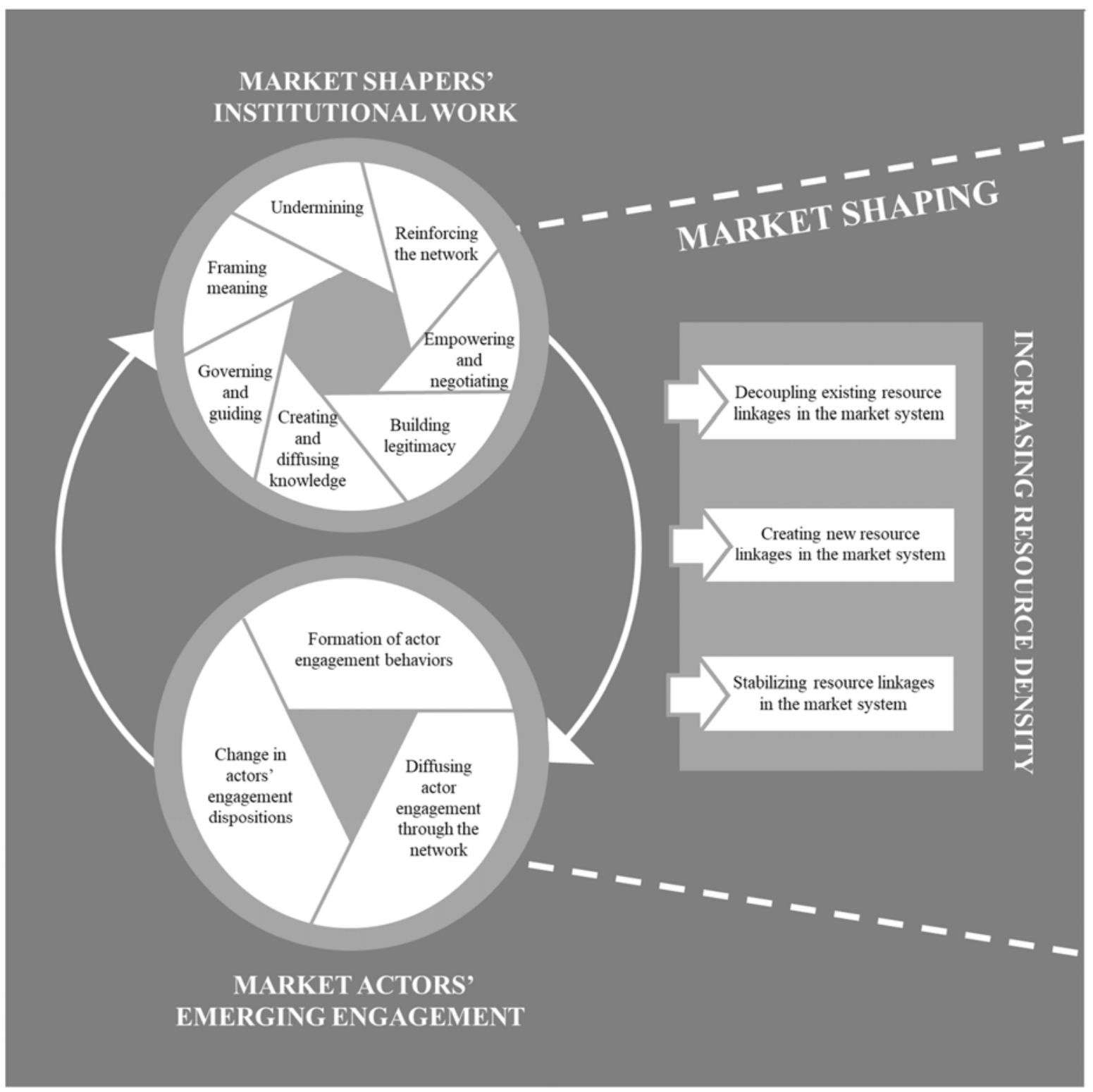


Illustrative case: Winding Tree (windingtree.com)

The Winding Tree, a decentralized blockchain-based marketplace for the travel industry, makes an ideal context for demonstrating the dynamics of market shaping as they relate to the interplay of AE and institutional work. The Winding Tree is the first public blockchain-based, open-source marketplace for travel services, and aims to make travel cheaper for consumers and more profitable for suppliers such as airlines, hotels, and tour operators and for sellers (travel agencies). It consists of sets of smart contracts developed on the blockchain Ethereum. Holders of Lif coins, the marketplace's cryptocurrency, can participate in further developing those contracts. Suppliers like hotels get to put information about their availability and price in the blockchain (database), where travel agencies can easily discover it then buy that inventory and pay for it instantly, again with Lif. All interactions are designed to operate without human intervention. A detailed map of Winding Tree's milestones to shape their blockchain-based marketplace, along with other pertinent information and sources for mentions below, can be found in Appendix A.

\section{Decoupling existing resource linkages in the market system}

Market shapers often start with the goal of shifting the balance of institutional (and market) power (Micelotta and Washington, 2013). The Winding Tree case makes plain how established resource linkages in the travel marketplace were disrupted to shift the balance in market power. This decoupling effect is illustrated by quotes in Table 2. With their whitepaper and various blog entries, Winding Tree argued that the travel industry is dominated by a handful of powerful platforms, such as Booking.com and Expedia. Hence, the argument ran, Winding Tree would cut out middle men in the travel market, with the decentralized network purposively undermining current market leaders (Micelotta and Washington, 2013). 
Further, by questioning the existing structure, pricing, and revenue system of the travel industry, Winding Tree (re)frames the meaning of established resource linkages, namely with the existing travel platforms. Framing (and reframing) meaning are core institutional work efforts, extensively researched (e.g. Helfen and Sydow, 2013; Jones and Massa, 2013). Undermining the market leaders and reframing the meaning and value system of the travel industry have changed the engagement dispositions of dozens of airlines and hotel brands; they decided to join forces to weaken existing structures and "retake" the industry (a word ringing with democratic appeal), using a public blockchain technology, open source and decentralized structures. This change in actors' engagement dispositions leads to the decoupling of existing resource linkages in the market system such as between hotels and platform providers like Booking.com, which opens up potential for disruptive market innovation and greater resource density.

Table 2. Decoupling existing resource linkages in market system

\begin{tabular}{|c|c|c|}
\hline $\begin{array}{l}\text { Market shapers' } \\
\text { institutional work }\end{array}$ & $\begin{array}{l}\text { Market actors' } \\
\text { engagement }\end{array}$ & $\begin{array}{l}\text { Effect on increasing } \\
\text { resource density in the } \\
\text { market system }\end{array}$ \\
\hline $\begin{array}{l}\text { Undermining } \\
\text { Questioning current market leaders }\end{array}$ & $\begin{array}{l}\text { Change in actors' } \\
\text { engagement } \\
\text { dispositions }\end{array}$ & $\begin{array}{l}\text { Decoupling existing } \\
\text { resource linkages in } \\
\text { market system }\end{array}$ \\
\hline $\begin{array}{l}\text { "In a decentralized travel distribution system, for } \\
\text { example, there is no room for rent-seeking } \\
\text { intermediaries, therefore the wealth they are } \\
\text { currently hoarding will be distributed to the rest } \\
\text { of the network, making travel cheaper for } \\
\text { travelers and more profitable for travel } \\
\text { companies." } \\
\text { Maksim Izmaylov, Founder \& CEO Winding } \\
\text { Tree) }\end{array}$ & $\begin{array}{l}\text { "Dozens of airlines and } \\
\text { hotel brands are joining } \\
\text { forces to retake their } \\
\text { industry with } \\
\text { blockchain." } \\
\text { (Finder.com) }\end{array}$ & $\begin{array}{l}\text { "Today, booking an } \\
\text { international flight involves } \\
\text { a multi-currency transaction } \\
\text { which can span a handful of } \\
\text { countries for a simple } \\
\text { flight... A single booking can } \\
\text { involve more than five } \\
\text { currency trades for a simple } \\
\text { flight if third-party } \\
\text { insurance or a car rental is }\end{array}$ \\
\hline $\begin{array}{l}\text { Framing meaning } \\
\text { Developing a new ideology and values } \\
\text { "Only open collaborations not for money, but for } \\
\text { innovation can make real fundamental change in } \\
\text { the world" } \\
\text { (Winding Tree white paper) }\end{array}$ & & $\begin{array}{l}\text { added to a booking at } \\
\text { checkout. Winding Tree } \\
\text { solves this problem by using } \\
\text { blockchain technology to } \\
\text { remove extensive currency } \\
\text { conversion from the travel } \\
\text { booking process". } \\
\text { (Winding Tree white paper) }\end{array}$ \\
\hline
\end{tabular}


Creating new resource linkages in the market system

Creating new linkages to make resources denser in the market system is arguably the central driving force for any market shaper's efforts (Nenonen et al., 2019; Storbacka, 2019). New resource linkages are built on the connections of actors in the market system and how these actors engage with one another, regardless whether the connections involve formal (e.g. hierarchical or contractual) or informal (non- or low-hierarchical) ties. All actors in the market system depend on and benefit from the resource integration that accompanies AE behaviors (Alexander et al., 2018; Brodie et al., 2019). However, for AE behaviors to form takes a certain degree of coordination or governance. The Winding Tree case highlights the market shaper's role in facilitating the formation of AE behaviors, again as illustrated by quotes in Table 3.

The decentralized infrastructure and new cryptocurrency developed by Winding Tree offer fresh ways of governing and guiding actors in their actions in the market system (Lawrence and Suddaby, 2006; Lawrence et al., 2013). For example, through the initial coin offering (ICO) of Lif tokens, a "crowd" of ordinary people was invited to engage with Winding Tree by funding the decentralized network and thereby becoming "token holders" (i.e. shareholders). Winding Tree, iteratively, was responsible for creating and diffusing knowledge about the blockchain and how the blockchain functions in the network (Laukkanen and Patala, 2014) and thereby created explicit procedures, which allowed the formation of actor engagement behaviors. For example, Winding Tree initiated experiential events, such as hackathons - a design-sprint event for software developers to collaborate intensively on software projects - to host blockchain developers from major airlines and hotel chains to try out and further develop this decentralized form of the technology.

The Winding Tree hackathon brought together major airlines, developers, and startups to collaborate on shared solutions for the first time. The participants built a joint language and vocabulary by openly exchanging expertise, giving feedback, and refining each other's hacks 
with fresh perspectives, communicating freely in the spirit of open innovation. Efforts like this not only created new resource linkages in the market system that increased resource density between various market actors but also established Winding Tree as the platform in the travel industry. Etihad airlines, for example, the flag carrier of United Arab Emirates, frankly declared their desire to disrupt traditionally siloed and dominated travel markets by experimenting with other airlines on the back of Winding Tree's support.

By letting travel agencies, airlines and hotels engage, Winding Tree as a platform builds legitimacy in the new market system, another core effort discussed in the institutional work literature (Zietsma and Lawrence, 2010). Winding Tree won the support of central players in the travel industry early in the process and experimented together with these companies to advance new institutional arrangements, notably its blockchain technology and the decentralized marketplace. The Winding Tree platform created engagement touchpoints for software developers, startups, evangelists, suppliers and sellers of travel services - and an open source environment for AE behaviors to form. While Winding Tree means different things to different actors, what is unambiguous is that the engagement platform provided by Winding Tree as a market shaper facilitates these new meanings (i.e. the development of new shared institutional arrangements) (Storbacka et al., 2016).

Creating new resource linkages in the market system thus flows from the formation of new or modified engagement behaviors between market actors. These engagement behaviors are coordinated through the market shaper (e.g. developer platform, hackathon), and aligned through new institutional arrangements (e.g. co-working agreements between competitors). 
Table 3. Creating new resource linkages in market system

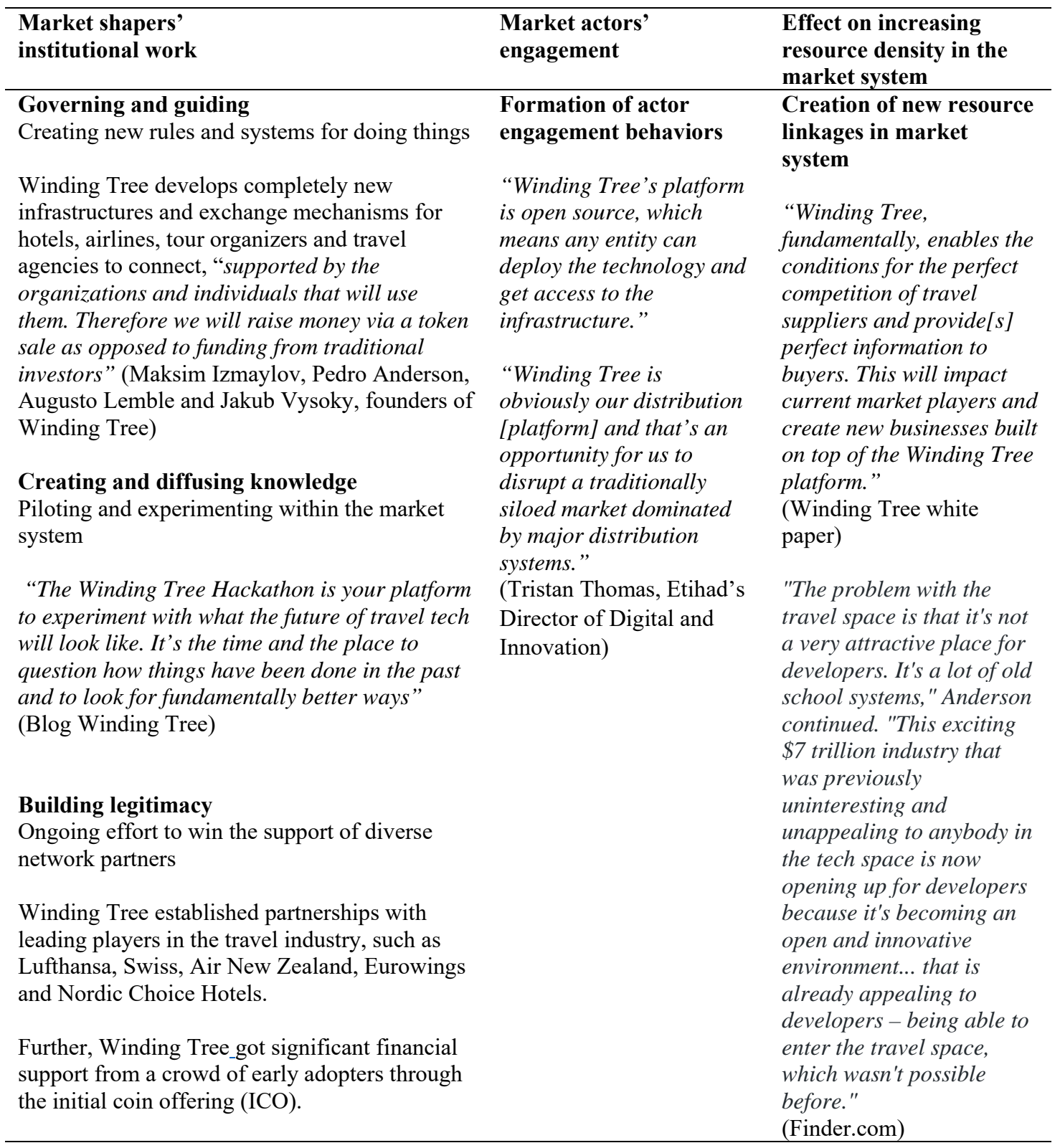


Stabilizing resource linkages in the market system

An institutional work perspective on market shaping promotes viewing market change processes from multiple system levels, across micro, meso and macro levels of aggregation (Wieland et al., 2017). Switching foci between micro (i.e. individual market actors), meso (e.g. industries and industry regulators), and macro levels (e.g. society) can help one understand the complexities of market systems, consisting as they do of adaptive and dynamic institutional change processes. The Winding Tree case illustrates this complexity. On a micro level, for example, by decoupling established resource linkages from established travel platforms, Winding Tree changes the engagement dispositions of individual hotels and travel agencies. Still at the micro-level, activities like the hackathons form AE behaviors amongst software developers and other actors. On a meso-level, Winding Tree encourages AE diffusion by setting new industry standards. Based on these, competitors agree to co-develop new solutions. Finally, on a macro-level Winding Tree's efforts to establish and legitimize blockchain technology spur international governments, airports and airlines to engage in a broader, societal institutional change by further developing blockchain technology and decentralized governance for the future of tourism.

Recent research on institutional work emphasizes the holistic view of institutional processes and the complex interplay between institutional change, creation and maintenance to overcome institutional resilience (Lawrence et al., 2013). The latter poses a crucial challenge for market shapers. Among others, Helfen and Sydow (2013) suggest that balancing the complex interplay between empowering and negotiating with market actors on various system levels is critical to attacking existing path dependencies and institutional resilience. While market shapers can no more change institutional arrangements alone than can any other sole actors, they can engage allies by communicating their visions for new ways of integrating resources and value creation practices in the market system (Vargo et al., 2020). Winding Tree 
relies on shared understandings of enrolled and engaged allies in order to perform institutional work. For example, it constantly empowers not only blockchain developers and potential holders of Lif tokens, but also the wider public to actively engage in the technological blockchain development and the evolution of decentralized market systems. This advances all market actors' tacit and explicit skills and know-how on engaging in the new marketplace.

Micelotta and Washington (2013) stress the importance of reinforcing the network and capture both efforts: change and maintenance of institutions. On this note, through their TED talks and podcasts, the founders of Winding Tree respond to unsolved issues about their blockchain technology. By themselves reflecting critically on the technology and its current development stage they evince openness and thus somewhat paradoxically breed trust and credibility, which are integral to diffusing actor engagement through the network. Because he trusts Winding Tree, Christian Lunden, Director of Future Business at Nordic Choice Hotels, is emphatic that the hotel group is looking forward to continuing to educate the industry about the importance of incorporating blockchain technology into the space. Such ongoing efforts of reinforcing, negotiating and empowering market actors' engagement are central to increasing resource density on all levels of the market system, as illustrated by the quotes in Table 4 . 
Table 4. Stabilizing resource linkages in the market system

\begin{tabular}{|c|c|c|}
\hline $\begin{array}{l}\text { Market shapers' } \\
\text { institutional work }\end{array}$ & $\begin{array}{l}\text { Market actors' } \\
\text { engagement }\end{array}$ & $\begin{array}{l}\text { Effect on increasing } \\
\text { resource density in the } \\
\text { market system }\end{array}$ \\
\hline $\begin{array}{l}\text { Empowering and negotiating } \\
\text { Balancing the complex interplay of negotiating with } \\
\text { and empowering market actors to overcome } \\
\text { institutional resistance }\end{array}$ & $\begin{array}{l}\text { Diffusing actor } \\
\text { engagement through the } \\
\text { network }\end{array}$ & $\begin{array}{l}\text { Stabilizing resource } \\
\text { linkages in the market } \\
\text { system }\end{array}$ \\
\hline $\begin{array}{l}\text { Winding Tree constantly empowers blockchain } \\
\text { developers, potential shareholders of Lif tokens, but } \\
\text { also the wider public to actively engage in the } \\
\text { technological blockchain development }\end{array}$ & $\begin{array}{l}\text { “Meanwhile, } \\
\text { international } \\
\text { governments, airline } \\
\text { companies, and airports } \\
\text { are starting to adopt } \\
\text { blockchain technology” } \\
\text { (Tokenpost.com) }\end{array}$ & $\begin{array}{l}\text { "Suppliers will have the } \\
\text { option to set a default } \\
\text { referral commission if } \\
\text { they wish to do so. If a } \\
\text { referral fee is set, any } \\
\text { individual who refers a } \\
\text { customer to the supplier }\end{array}$ \\
\hline $\begin{array}{l}\text { Ongoing efforts to maintain and grow the new } \\
\text { market system }\end{array}$ & $\begin{array}{l}\text { "The ability to make } \\
\text { reservations on a public }\end{array}$ & $\begin{array}{l}\text { will automatically receive } \\
\text { the referral amount set by } \\
\text { [the] hotel. Hotels can }\end{array}$ \\
\hline $\begin{array}{l}\text { Winding Tree constantly works on improving the } \\
\text { platform and the platform-based market place. } \\
\text { "About } 100 \text { companies have already signed up to } \\
\text { build applications on Winding Tree, and those } \\
\text { companies will receive guidance and participate in } \\
\text { troubleshooting for the platform." } \\
\text { (Business Travel News). }\end{array}$ & $\begin{array}{l}\text { blockchain is a huge } \\
\text { achievement, and we're } \\
\text { looking forward to } \\
\text { continuing to educating } \\
\text { the industry about the } \\
\text { importance of } \\
\text { incorporating blockchain } \\
\text { technology into the } \\
\text { space.” } \\
\text { (Christian Lunden, } \\
\text { Director of Future } \\
\text { Business at Nordic Choice } \\
\text { Hotels) }\end{array}$ & $\begin{array}{l}\text { also set up individual } \\
\text { referral rates for different } \\
\text { entities if they wish to do } \\
\text { so. Winding Tree will be } \\
\text { deployed on the Ethereum } \\
\text { blockchain and may be } \\
\text { deployed on several other } \\
\text { blockchains in the future, } \\
\text { which guarantees } 100 \% \\
\text { uptime.” } \\
\text { (Winding Tree white } \\
\text { paper) }\end{array}$ \\
\hline
\end{tabular}

\section{Theoretical implications and areas for further research}

Taking the perspective that markets are socially constructed by interacting market actors, this paper contributes to the emerging stream of literature on market shaping and market innovation. The article conceptualizes the dynamic interplay between market shapers' deliberate efforts to manipulate their institutional context on the one hand, and the engagement of other market actors in this process on the other as the interplay between the two crucially intensifies resource density. Doing so yields a correspondingly dynamic, iterative framework for market shaping. Specifically, by building on the recognition of markets as dynamic systems that can be formed and re-formed (Nenonen et al., 2014; Nenonen et al. 2019), the authors conceptualize AE as a 
key way for markets to evolve and change, supported by institutional work (Baker et al., 2020). The conceptualization, and the illustration of it through the Winding Tree case, turn on appreciating the engagement processes of versatile market actors: In concert with other actors, market shapers create, decouple and stabilize resource linkages in market systems. As these new resource linkages evolve they make access to resources denser and thus markets can be shaped. This paper complements Baker and Nenonen's (2020) recent case study on market work. That study broadens the understanding of institutional work from the typical spotlight on the actions of one focal actor, to, as it were, a more "floodlit" stage of market work undertaken by collective actors, and thus sheds light on the emergent and iterative process of engaging them.

The dynamic framework distilled above from the literature review reveals seven types of institutional work of particular import to influencing institutional arrangements in market systems. To recap, the seven are: undermining current market leaders, (re)framing meaning, governing and guiding collective action of market actors, creating and diffusing knowledge, building legitimacy in the market, empowering and negotiating with the network, and reinforcing the network. Arguably, an institutional view of markets emphasizes ongoing adjustments and reconciliation processes of the market shaper's institutional work and the engagement of other market actors. Note that not only firms, but all market actors may, at some point during the process of engagement, become market shapers. The illustrative case used here, the Winding Tree decentralized travel marketplace, epitomizes the interplay between institutional work by the market shaper - namely the Winding Tree founders, who industriously produced whitepapers, blogs, a hackathon and so on - and the fruits of that labour in the other actors they induced to engage in creating, decoupling and stabilizing resource linkages. Together they made the market system more resource-dense. To the current understanding of 
AE in networks (Brodie et al., 2019) these insights add a more nuanced view of stimulating other market actors to engage on all levels of the market system.

These contributions now offer a foundation for extensive future research opportunities. Four main potential research areas emerge in the sections below, which should be read with Table 5. In particular, they invite research that 1) further elaborates on institutional work and how to operationalize it in market systems, 2) the multi-level perspective of AE and how to model dynamic engagement processes, 3) the influence of engagement on increasing resource density and more general, 4) actor-to-actor approaches to market shaping.

\section{Research Area 1: Exploring and testing institutional work to shape markets}

Developing a broader systemic and dynamic perspective on market formation requires new frameworks, classifications, and measurement tools. Research in market shaping is embryonic, and discussion on institutional work for market shaping only just beginning. The seven types of institutional work to facilitate market shaping via AE lay a foundation for research to conceptually extend and empirically examine the greater conceptual framework proposed here. However, the seven types do not claim to be exhaustive. Analysis in other market shaping contexts may turn up fresh types of institutional work and there remains an opportunity to empirically examine and test these categories and their effect on market shaping.

Furthermore, existing institutional work studies mainly concentrate on changes at an organizational micro-level (Baker et al., 2018). The present paper suggests that institutional work can foster AE on any market system level, be it micro, meso or macro. Hence, scholars may want to explore alternative research frameworks that expand the perspective from validating markets to shaping markets (Nenonen et al., 2018) as well as to account for institutional change on various system levels. 
Research Area 2: Exploring market shaping through AE on multiple levels of market systems A multi-level perspective of market shaping is not only the overture to a new discussion about measurement frameworks; it also requires alternative ways to conceptualize and explore the dynamic and iterative process of AE in market systems. Responding to Brodie et al.'s (2019) call for further investigating the dynamic and iterative process of AE on a system level, this article has conceptualized and illustrated that market shapers need to engage allies on many system levels, including for instance other companies, communities, and governments, to collectively drive market change. For example, the founders of Winding Tree received substantial support from a broad sweep of market actors numbering among them hotels, airlines, developers, the wider public, and governments, because they intentionally brought diverse and influential groups like thought-leading bloggers and developers into the tent with events like a hackathon, TED talks and keynote speeches to name a few. These broad-based and multi-level efforts at performing institutional work assume special importance when strong forces oppose new market practices and new technology like Winding Tree's blockchain technology.

Systematically oscillating one's focus on AE between the micro, meso and macro level can help both scholars and practitioners discern the complexities of disrupting, creating and maintaining institutions. There is potential for further investigating how AE diffuses across system levels and how market shapers engage and "recruit" other actors and new market shapers, to collectively drive market change and market innovation.

\section{Research Area 3: Exploring increasing resource densities in markets}

Extending the work on market shaping by Nenonen et al. (2019) and Storbacka (2019), the dynamic framework above offers a nuanced view on creating new resource linkages. In particular, it proposes three ways of increasing resource density in the market: creating new resource linkages; decoupling existing resource linkages, for example, by undermining existing 
partnerships with the market leader; and stabilizing resource linkages to create trust and credibility in the market system. In future, significant contributions could be made in advancing knowledge about the interplay between decoupling, creating, and stabilizing resource linkages in market systems. Furthermore, the potential conflicts and barriers in the way of creating new linkages make intriguing avenues for further research. More generally, the process of increasing resource density and value creation in market systems deserves reflection and exploration.

\section{Research Area 4: Developing an actor-to-actor approach to market shaping}

Finally, as the conceptual understanding of market shaping grows by considering institutional work and AE together, it must draw from a wider array of theories that underpin an actor-toactor perspective and systemic thinking. These include neo-institutional theory, institutional work, and service-dominant logic. Scholars could very fruitfully continue using systemic theoretical frameworks to better comprehend $\mathrm{AE}$ and networks in market shaping. Such frameworks might include practice theory (Bourdieu, 1990), complexity theory (Anderson, 1999), systemic design theories (Buchanan, 1992; Sevaldson, 2017; Windahl et al., 2020), structuration theory (Giddens, 1984), and entrepreneurial theories (Sarasvathy, 2001). This paper has argued that the market shaper undertakes institutional work and induces other actors to engage. It stresses that not only focal firms can be market shapers; indeed, every actor who engages is partially responsible for the market being shaped. Consequently, future research should elaborate on the role of other actors including customers, activists, citizens, social collectives, governments, and others in shaping markets. Table 5 summarizes relevant research questions of the four research areas. 


\begin{tabular}{|c|c|}
\hline Research Areas: & Research Questions: \\
\hline $\begin{array}{l}\text { Research Area 1: } \\
\text { Exploring and } \\
\text { testing } \\
\text { institutional work } \\
\text { to shape markets }\end{array}$ & $\begin{array}{l}\text { - What additional types of institutional work can be found in other contexts } \\
\text { of market shaping? } \\
\text { - How can the impact of different institutional work efforts on market } \\
\text { - How can me operationalized and tested? } \\
\text { benchmark for market shaping (as opposed to market validation)? } \\
\text { - How can these frameworks be designed to account for institutional } \\
\text { change on various levels of the market system? }\end{array}$ \\
\hline $\begin{array}{l}\text { Researc } \\
\text { Explori } \\
\text { shaping } \\
\text { AE on n } \\
\text { levels of } \\
\text { systems }\end{array}$ & $\begin{array}{l}\text { - How does AE diffuse across system levels? And how can this contagion } \\
\text { of engagement be coordinated and funneled towards market shaping? } \\
\text { - What degree of formality (i.e. contracts, industry standards, defined } \\
\text { processes, etc.) best supports diffusing AE? } \\
\text { - How can market shapers engage and "recruit" new market shapers, i.e. } \\
\text { allies, such as other companies, communities, and the government to } \\
\text { collectively drive market change? }\end{array}$ \\
\hline $\begin{array}{l}\text { h Area 3: } \\
\text { ng } \\
\text { ng } \\
\text { density } \\
\text { et systems }\end{array}$ & $\begin{array}{l}\text { - When do resource linkages have to be decoupled, created or stabilized in } \\
\text { - order to increase resource density? And what is the right timing for it? } \\
\text { - What are the conflicts and barriers when creating new resource linkages? } \\
\text { - When do resource linkages become useful for market shaping? }\end{array}$ \\
\hline $\begin{array}{l}\text { Research Area 4: } \\
\text { Developing an } \\
\text { actor-to-actor } \\
\text { approach to } \\
\text { market shaping }\end{array}$ & $\begin{array}{l}\text { - How do other actors, including customers, activists, citizens, } \\
\text { communities, governments, etc. shape markets? } \\
\text { - If all actors engage in institutional work to shape markets, what does the } \\
\text { dynamic interplay of these actors look like? When do engaged actors } \\
\text { become market shapers? } \\
\text { - How can theoretical frameworks, including practice theory, service- } \\
\text { dominant logic, complexity theory, design theories, structuration theory, } \\
\text { sociology of technology and entrepreneurial theories further inform an } \\
\text { actor-to-actor perspective in market shaping? }\end{array}$ \\
\hline
\end{tabular}




\section{Practical implications}

This study provides new insights for managers, entrepreneurs and policymakers aiming to shape markets, including those involved in radical and deep-tech innovations, where, problematically, existing engagement behaviors of market actors must yield before new technologies can be adopted. Rather than taking markets for granted, the article has argued that markets can be shaped through the purposive actions of entrepreneurs and innovators (Gosling et al., 2017; Nenonen et al., 2019; Mele et al., 2014), if these purposive actions suitably alter other market actors' engagement dispositions and behaviors. Major consequences flow for the normative tools and methods used to evaluate market potential. Thus, practitioners need to modify how they evaluate markets to more deeply comprehend iterative and dynamic processes that foster engagement, rather than purely assessing existing market potential.

Further, accepting that markets are shaped suggests that markets and $\mathrm{AE}$ are in a constant state of flux. While institutional work can help channel this flux (Lawrence and Suddaby, 2006), it cannot be "managed". Thus, strategies for operating successfully in evolving markets have to be highly dynamic and agile. They must allow for feedback between market actors' engagement and market shapers' actions. Finally, the proposed analytical catalogue of seven institutional work types takes on practical application as a portfolio and equips would-be market-shaping practitioners with tangible and actionable insights into how to enact institutional change by undermining existing structures, by knowledge creation and diffusion, and by developing networks and building legitimacy in their market systems.

\section{Conclusion}

Contemporary business environments, digital economies, sharing economies and present and potential future blockchain economies have intensified the need to reconceptualize our view of markets and how they form and re-form. This conceptual paper has introduced a dynamic 
market shaping framework building on the interplay of market actors' institutional work and AE: how such deliberate efforts of the market shaper trigger engagement processes of other market actors to collectively drive market change. This framework draws from, and extends, recent works that describe markets as malleable, emergent and dynamic (Baker et al., 2018; Gosling et al., 2017; Nenonen et al., 2019). The holistic framework here underlines that institutional work and $\mathrm{AE}$ are fundamental means to decouple existing resource linkages, create new ones, and stabilize others and thereby increase resource density and value creation in market systems. 


\section{References}

Alexander, M.J., Jaakkola, E., and Hollebeek, L.D. (2018), “Zooming out: actor engagement beyond the dyadic", Journal of Service Management, Vol. 29 No. 3, pp. 333-351.

Anderson, P. (1999), "Perspective: Complexity theory and organization science", Organization science, Vol. 10 No. 3, pp. 216-232.

Araujo, L. (2007), "Markets, market-making and marketing”, Marketing Theory, Vol. 7 No. 3, pp. 211-226.

Aspers, P. (2007), "Theory, Reality, and Performativity in Markets”, The American Journal of Economics and Sociology, Vol. 66 No. 2, pp. 379-398.

Baker J., Fehrer J.A., and Brodie R.J. (2020), "Service Dominant Logic and Market Innovation”, in Bridges, E. and Fowler, K. (Eds.), Service Insights and Trends, Routledge, New York.

Baker, J.J., and Nenonen, S. (2020), "Collaborating to shape markets: Emergent collective market work." Industrial Marketing Management, Vol. 85, pp. 240-253.

Baker, J.J., Storbacka, K., and Brodie, R.J. (2018), "Markets changing, changing markets: Institutional work as market shaping", Marketing Theory, Vol. 19 No. 3, pp. 301-328.

Battilana, J. and D'Aunno, T. (2009), "Institutional work and the paradox of embedded agency", in Lawrence, T.B., Suddaby, R. and Leca, B. (Eds.), Institutional Work: Actors and Agency in Institutional Studies of Organizations, Cambridge University Press, Cambridge, UK, pp. 31-58.

Bourdieu, P. (1990), The logic of practice. Stanford University Press.

Bowden, J.L.H., Conduit, J., Hollebeek, L.D., Luoma-Aho, V. and Solem, B.A. (2017), "Engagement valence duality and spillover effects in online brand communities", Journal of Service Theory and Practice, Vol. 27 No. 4, pp. 877-897.

Breidbach, C.F. and Brodie, R.J. (2017), "Engagement platforms in the sharing economy: conceptual foundations and research directions", Journal of Service Theory and Practice, Vol. 27 No. 4, pp. 761-777.

Brodie, R.J., Fehrer, J.A., Jaakkola, E., and Conduit, J. (2019), “Actor Engagement in Networks: Defining the Conceptual Domain”, Journal of Service Research, Vol. 22 No. 2, pp. 173-188.

Brodie, R.J., Hollebeek, L.D., Juric, B. and Ilic, A. (2011), "Customer engagement: conceptual domain, fundamental propositions, and implications for research", Journal of Service Research, Vol. 14 No. 3, pp. 252-271. 
Brodie, R.J., Ilic, A., Juric, B. and Hollebeek, L.D. (2013), “Consumer engagement in a virtual brand community: An exploratory analysis", Journal of Business Research, Vol. 66 No. 1, pp. 105-114.

Buchanan, R. (1992), “Wicked problems in design thinking”, Design issues, Vol. 8 No. 2, pp. $5-21$.

Edvardsson, B., Kleinaltenkamp, M., Tronvoll, B., McHugh, P., and Windahl, C. (2014), "Institutional logics matter when coordinating resource integration", Marketing Theory, Vol. 14 No. 3, pp. 291-309.

Edvardsson, B., Tronvoll, B., and Gruber, T. (2011), "Expanding understanding of service exchange and value co-creation: a social construction approach", Journal of the Academy of Marketing Science, Vol. 39 No. 2, pp. 327-339.

Giddens, A. (1984), The Constitution of Society: Outline of the Theory of Structuration, Cambridge, England: Polity Press.

Gosling, M., Richard, J., and Seo, Y. (2017), "Markets and market boundaries: a social practice approach.” Journal of Service Theory and Practice, Vol 27. No. 2, pp. 408-426.

Harmeling, C.M., Moffett, J.W., Arnold, M.J. and Carlson, B.D. (2017), "Toward a theory of customer engagement marketing", Journal of the Academy of Marketing Science, Vol. 45 No. 3, pp. 312-335.

Helfen, M. and Sydow, J. (2013), "Negotiating as institutional work: The case of labour standards and international framework agreements", Organization Studies, Vol. 34 No. 8, pp. 1073-1098.

Jaakkola, E. and Alexander, M. (2014), "The role of customer engagement behavior in value co-creation: a service system perspective", Journal of Service Research, Vol. 17 No. 3, pp. 247-261.

Jaakkola, E., Conduit, J. and Fehrer, J. (2019), "Tracking the Evolution of Engagement Research: Illustration of Midrange Theory in the Service-Dominant Paradigm, in Vargo, S. and Lusch, R. (eds.) The SAGE Handbook of Service Dominant Logic, SAGE, pp. 580-598.

Jones, C. and Massa, F.G. (2013), "From Novel Practice to Consecrated Exemplar: Unity Temple as a Case of Institutional Evangelizing”, Organization Studies, Vol. 34 No. 8, pp. 1099-1136.

Kleinaltenkamp, M., Karpen, I. O., Plewa, C., Jaakkola, E., and Conduit, J. (2019), "Collective engagement in organizational settings", Industrial Marketing Management, Vol. 80, pp. 11-23. 
Laukkanen, M. and Patala, S. (2014), “Analysing barriers to sustainable business model innovations: Innovation systems approach", International Journal of Innovation Management, Vol. 18 No. 6, pp. 1-21.

Lawrence, T. B., Leca, B., and Zilber, T.B. (2013), "Institutional Work: Current Research, New Directions and Overlooked Issues”, Organization Studies, Vol. 34 No. 8, pp. 10231033.

Lawrence, T.B. and Suddaby, R. (2006), "Institutions and institutional work", The SAGE Handbook of Organizational Institutionalism, pp. 215-254.

Lawrence, T.B., Suddaby, R., and Leca, B. (2009), "Institutional Work: Actors and Agency in Institutional Studies of Organizations", Cambridge University Press, Cambridge, UK.

Mele, C., Pels, J., and Storbacka, K. (2014), “A holistic market conceptualization”, Journal of the Academy of Marketing Science, Vol. 43 No. 1, pp. 1-15

Micelotta, E.R. and Washington, M. (2013), "Institutions and Maintenance: The Repair Work of Italian Professions”, Organization Studies, Vol. 34 No. 8, pp. 1137-1170.

Möller, K., and Rajala, A. (2007), "Rise of strategic nets-New modes of value creation", Industrial Marketing Management, Vol. 36 No. 7, pp. 895-908.

Nenonen, S., Kjellberg, H., Pels, J., Cheung, L., Lindeman, S., Mele, C., and Storbacka, K. (2014), "A new perspective on market dynamics: Market plasticity and the stabilityfluidity dialectics", Marketing Theory, Vol. 14 No. 3, pp. 269-289.

Nenonen, S., Storbacka, K., and Frethey-Bentham, C. (2018), "Is your industrial marketing work working? Developing a composite index of market change", Industrial Marketing Management, Vol. 80, pp. 251-265.

Nenonen, S., Storbacka, K., and Windahl C. (2019), "Capabilities for market-shaping: triggering and facilitating increased value creation. Journal of the Academy of Marketing Science.

Normann, R. (2001), Reframing business: When the map changes the landscape. Chichester: Wiley.

North, D.C. (1990), “A transaction cost theory of politics", Journal of Theoretical Politics, Vol. 2 No. 4, pp. 355-367.

Phillips, N. and Lawrence, T.B. (2012), "The turn to work in organization and management theory: Some implications for strategic organization", Strategic Organization, Vol. 10 No. 3, pp. 223-230.

Raviola, E., and Norbäck, M. (2013), "Bringing technology and meaning into institutional work: Making news at an Italian business newspaper”, Organization Studies, Vol. 34 No. 
8, pp. 1171-1194.

Sarasvathy, S.D. (2001), "Causation and effectuation: Toward a theoretical shift from economic inevitability to entrepreneurial contingency", Academy of Management Review, Vol. 26 No. 2, pp. 243-263.

Sharma, S., and Conduit, J. (2016), "Cocreation culture in health care organizations", Journal of Service Research, Vol. 19 No. 4, pp. 438-457.

Schatzki, T.R., Knorr-Cetina, K. and Savigny, E.V. (2001), The practice turn in contemporary theory", New York: Routledge.

Scott, W.R. (2014), Institutions and organizations: Ideas, interests, and identities (4th ed.). Thousand Oaks, CA: Sage Publications, Inc.

Sevaldson, B. (2017), "Redesigning Systems Thinking”, FormAkademisk, Vol. 10 No. 1, pp. $1-23$.

Storbacka, K. (2019), “Actor engagement, value creation and market innovation”, Industrial Marketing Management, Vol. 80, pp. 4-10.

Storbacka, K., Brodie, R.J., Böhmann, T., Maglio, P.P., and Nenonen, S. (2016), “Actor engagement as a microfoundation for value co-creation”, Journal of Business Research, Vol. 69 No. 8, pp. 3008-3017.

Storbacka, K. and Nenonen, S. (2011), "Scripting markets: from value propositions to market propositions”, Industrial Marketing Management, Vol. 40 No. 2, pp. 255-266.

Storbacka, K., and Nenonen, S. (2015), "Learning with the market: Facilitating market innovation”, Industrial Marketing Management, Vol. 44, pp. 73-82.

van Doorn, J., Lemon, K.N., Mittal, V., Nass, S., Pick, D., Pirner, P. and Verhoef, P.C. (2010), "Customer engagement behavior: theoretical foundations and research directions”, Journal of Service Research, Vol. 13 No. 3, pp. 253-266.

Vargo, S.L., Akaka, M.A., and Wieland, H. (2020), „Rethinking the process of diffusion in innovation: A service-ecosystems and institutional perspective" Journal of Business Research, https://doi.org/10.1016/j.jbusres.2020.01.038.

Vargo, S.L. and Lusch, R.F. (2016), "Institutions and axioms: an extension and update of service-dominant logic", Journal of the Academy of Marketing Science, Vol. 44 No. 1, pp. 5-23.

Vargo, S.L., Wieland, H., and Akaka, M.A. (2015), "Innovation through institutionalization: A service ecosystems perspective." Industrial Marketing Management, Vol. 44, pp. 6372. 
Verleye, K., Gemmel, P., and Rangarajan, D. (2014), "Managing engagement behaviors in a network of customers and stakeholders evidence from the nursing home sector", Journal of service research, Vol. 17 No. 1, pp. 68-84.

Wieland, H., Hartmann, N.N. and Vargo, S.L. (2017), "Business models as service strategy", Journal of the Academy of Marketing Science, Vol. 45 No. 6, pp. 925-943.

Windahl, C., Karpen I.O., and Wright M.R.. (2020), "Strategic design: orchestrating and leveraging market-shaping capabilities." Journal of Business \& Industrial Marketing, in print.

Wieland, H., Koskela-Huotari, K. and Vargo, S.L. (2016), "Extending actor participation in value creation: an institutional view", Journal of Strategic Marketing, Vol. 24 No. 3/4, pp. 210-226.

Zietsma, C., and Lawrence, T.B. (2010), "Institutional work in the transformation of an organizational field: The interplay of boundary work and practice work", Administrative science quarterly, Vol. 55 No. 2, pp. 189-221. 


\section{Appendix A}

\section{Winding Tree milestones}

\section{Q1}

- 7,082 Initial Coin Offering (ICO)

\section{7}

- Announcements of partnerships with Airport Hotel Basel, ZeppelinOS, RSK

- Joins HTNG global not-for-profit association in hospitality

- Featured in award-winning series on Fox Business Channel

\section{Q4}

- Announcements of partnerships with Air France-KLM, Air Canada, Airport Hotel Basel

- Announcement technological partnership with Sciant

- First Winding Tree Hackthon

- Receives Innovation of the Year Award from CAPA Centre for Aviation

- Proof of Content on Winding Tree Platform to scale data structure, smart contracts and data distribution processes

\section{Q4}

- Lif Token Distribution prior to Initial Coin Offering (ICO)

- Building up relationships in blockchain networks (e.g. ICO crowd, ICO alert, TokenMarket)

- Integrates Lif Token Wallet

- Announcements of partnerships with Lufthansa, Swiss, Austrian Airlines, Brussels Airlines, Eurowings, Air New

2018 Zealand, Island of Aruba, Nordic Choice Hotels

\section{Q2 and Q3}

- Announcements of partnerships with Swissport International AG, citizenM, eRevMax

- Start of weekly updates on the development process of the platform (e.g., development Winding Tree search engine and open source data exchange standards for airlines)

- Announcement of technological partnership with Siesta Cloud

\section{9}

- Real inventory distribution

- Improvement network scalability and privacy

- Second Winding Tree Hackathon

- Winding Tree Roundtable 


\section{Winding Tree partnerships and activities:}

- Lufthansa agrees to participate in the pre-sale of Winding Tree's cryptocurrency Líf

- Air New Zealand collaborates to improve booking and pre-booking operations and invests in ICO

- Island of Aruba collaborates to connect tourists directly with local travel suppliers

- Nordic Choice Hotels (Stockholm) participates in the pre-sale of Winding Tree's cryptocurrency Líf and tests open-source blockchain distribution platform

- Collaboration with Jaxx Wallet to integrate the Lif token wallet

- Winding Tree joins Hospitality Technology Next Generation (HTNG) not-for-profit organization

- Collaboration with Airport Hotel Basel, citizenM Boutique hotels, Airport Hotel Basel in order to integrate blockchain technology into hospitality system

- Winding Tree collaborates with ZeppelinOS, an open framework of smart contracts and RSK, an open-source smart contract platform powered by the Bitcoin network

- Collaboration with Swissport International AG, the global leader in airport ground services and air cargo handling

- Collaboration with the travel and hotel distribution systems eRevMax and Siesta Cloud

- Collaboration with Air Canada and Air France-KLM to give blockchain-savvy users the ability to access airline content directly from the source

- Technological partnership with Sciant, a software outsourcing provider that focuses on travel technology

- Winding Tree hackathon in Prague bringing together all airlines, hotels, industry experts, travel startups and blockchain enthusiasts to further develop the blockchain 


\section{Winding Tree social media:}

- Facebook (7096 Followers)

- Twitter (5091 Readers)

- Telegram (2348 Members) and Official Winding Tree Chat

- Blog Winding Tree at Medium Community platform https://blog.windingtree.com (1.7k Followers)

- Reddit (932 Subscribers)

- Youtube (531 Subscribers)

- GitHub (largest software developer community): regular posts

\section{Winding Tree online publications / press releases / podcasts / TED talks:}

- Winding Tree website https://windingtree.com

- Winding Tree white paper https://cryptorating.eu/whitepapers/WindingTree/WT_OP_ENG.pdf

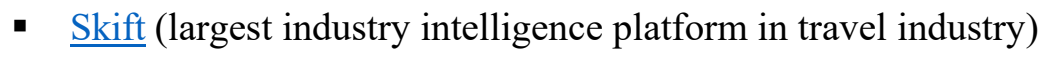
https://skift.com/2017/08/07/channel-shock-the-future-of-traveldistribution/?utm_content=bufferf1f4a\&utm_medium=social\&utm_source=twitter.co $\underline{\text { m\&utm campaign=buffer }}$

- TNW media https://thenextweb.com/money/2017/09/08/1075124/?utm_content=buffer16bae\&utm medium=social\&utm_source=twitter.com\&utm_campaign=buffer

- Blockchain News https://www.the-blockchain.com/2017/09/08/blockchain-travelmanuel-araoz-joins-winding-trees-efforts-decentralize-travelindustry/?utm_content=buffer780c8\&utm_medium=social\&utm_source=twitter.com \&utm campaign=buffer

- Forbes https://www.forbes.com/sites/francistapon/2018/02/12/what-winding-treesico-and-its-blockchain-based-technology-mean-to-the-travel-industry/\#30139ac344dc

- Financial Times https://www.ft.com/content/06bb9a76-c7b7-11e8-ba8f$\underline{\text { ee390057b8c9 }}$

- PhocusWire https://www.phocuswire.com/Air-France-KLM-takes-the-Winding-Treeroad 
- https://www.finder.com.au/inside-the-blockchain-coup-at-the-heart-of-the-travelindustry

- Travel Pulse https://www.travelpulse.com/news/travel-technology/tiny-start-up-seeksto-reinvent-traveldistribution.html?utm_content $=60880083 \& u t m \_$medium $=$social\&utm_source $=$twitter

- https://www.finder.com.au/inside-the-blockchain-coup-at-the-heart-of-the-travelindustry

- https://uk.reuters.com/article/us-blockchain-airlines-etihad/emirates-etihad-partnerswith-swiss-blockchain-platform-winding-tree-idUKKCN1UY2A9

- https://www.ccn.com/future-flight-air-new-zealand-experimenting-ethereum$\underline{\text { blockchain/ }}$

- Future Tech Podcast https://www.futuretechpodcast.com/podcasts/pedro-andersoncoo-of-winding-tree-a-decentralized-open-source-blockchain-platform-for-the-travelindustry/

- https://www.ledgerinsights.com/winding-tree-air-france-air-canada-publicblockchain-hotel-booking/

- https://buyingbusinesstravel.com/news/winding-tree-completes-blockchain-hotelbooking/

- https://tokenpost.com/Etihad-Airways-to-integrate-Winding-Trees-blockchainplatform-2968

- https://tokenpost.com/Etihad-Airways-to-integrate-Winding-Trees-blockchainplatform-2968

- Live sessions https://www.youtube.com/watch?v=bcRbpFjn07A

- TED Talks and Public Tech Talks (TEDxTUBerlin, Phocuswright Europe 2018, Amsterdam)

https://www.youtube.com/watch?v=rg2CXiK7Jw4 https:/www.youtube.com/watch?v=35Q-yX7Z4jM

- Fox TV Channel http://www.prweb.com/releases/2018/03/prweb15336928.htm

- Winding Tree Hackathon https://blog.windingtree.com/hacktravel-hackathon-recapfeacb65cc47d

- Workshops on blockchain distribution https://blog.windingtree.com/2018-q2roundup-18ca0cef7603 


\section{Winding Tree conferences and events:}

In 2018 the Winding Tree team participated in or gave 40+ talks on decentralized distribution at major technology events, including:

- London Blockchain Week (London, UK)

- TNABC, The North American Bitcoin Conference

- HOTCO, Hotel Investment Conference (Budapest, Hungary)

- Hamburg Aviation Conference (Hamburg, Germany)

- Bitcoin Super Conference (Irving, Texas, US)

- ITB Berlin (Berlin, Germany)

- SXSW \& Crypto Summit (Austin, TX, US)

- HT NEXT (San Diego, CA, US)

- EyeForTravel (San Francisco, CA, US)

- Blockchain for Travel (Mallorca, Spain)

- OffDevcon (Prague, Czech Republic)

- Future Blockchain Summit (Dubai, UAE)

- Phocuswright Europe (Amsterdam, Netherlands)

- Onyx Future Source (Dallas, TX, US)

- CAPA Airline Leader Summit (Dublin, Ireland)

- Travel Disruption Summit (New York, US)

- Blockchain For Travel (Mallorca, Spain)

- TEDxTUBerlin (Berlin, Germany)

- EyeForTravel Europe Show (London, UK)

- Travel Tech Con 2018 (San Francisco, CA, US)

- Pycon CZ (Prague, Czech Republic)

- HEDNA Europe (Lisbon, Portugal)

- EMERCE eTravel (Amsterdam, Netherlands)

- Travel Tech Con 2018 (San Francisco, CA, US) 